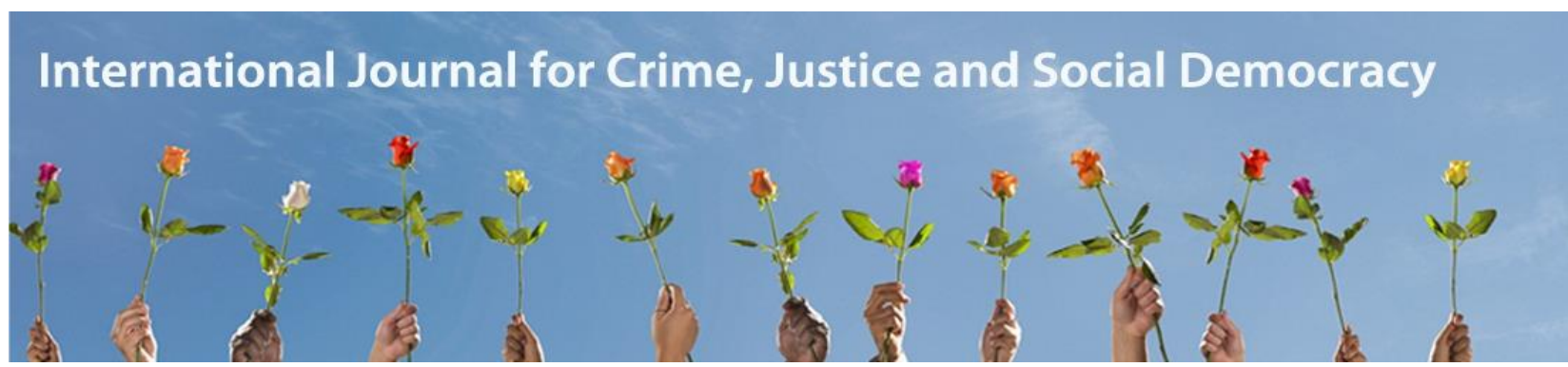

\title{
A Changing and Multi-scalar EU Borderscape: The Expansion of Asylum and the Normalisation of the Deportation of EU and EFTA Citizens
}

José A Brandariz and Cristina Fernández-Bessa

Universidade da Coruña, Spain

\begin{abstract}
The sorting of individuals is one critical function performed by migration law. These legal regulations are based on dichotomies, such as separating irregular migrants from regular migrants. However, through the multi-scalar management of human mobility, the conflicting coexistence of national and supranational interests decentres these legal binaries. Therefore, migration law devices sort newcomers in a more complex way, giving shape to multilayered and unstable hierarchies of otherness. Using Spain as a case study on migration control changes, this paper addresses the role that migration law enforcement institutions play in cementing and eroding these legal categories. First, it analyses the consequences of the so-called 'migration crisis' in enlarging a European asylum system that, until recently, seemingly rests on few countries. Second, it examines the increasing normalisation of the forced return of European Union (EU) (and European Free Trade Association [EFTA]) nationals, which undermine a critical prerogative of the EU citizenship status.
\end{abstract}

\section{Keywords}

Migration law enforcement; asylum; deportation of EU nationals; multi-scalar migration management; migration crisis.

Please cite this article as:

Brandariz JA and Fernández-Bessa C (2020) A changing and multi-scalar EU borderscape: The expansion of asylum and the normalisation of the deportation of EU and EFTA citizens. International Journal for Crime, Justice and Social Democracy 9(3): 21-33. https://doi.org/10.5204/ijcjsd.v9i3.1587

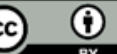




\section{Introduction}

Border regimes are sovereign apparatuses (Brown 2014; Huysmans 2006; Kanstroom 2012) aimed at governing human mobility. These regimes have consequences of utmost importance, such as stratifications of belonging and alienness, and hierarchies of rights and living conditions (Aas 2011). Their operation is based on classification guidelines and ordering processes (De Genova 2017; Follis 2011; van Houtum and van Naerssen 2002) that are particularly needed in a time in which bordering tasks are expected to be carried out swiftly and efficiently (Frontex and Fergusson 2015). In fact, supranational and especially national border protection apparatuses are compelled to constantly improve their selection capacities without slowing down authorised mobility flows. Therefore, border regimes require formalised protocols that allow border agents to perform the border (Wonders 2006) by making 'just-in-time' decisions. Beyond the indispensable assistance provided by Schengen databases and biometric technologies, citizenship is a critical selection criterion and plays a key role within the framework of the increasing utilisation of risk profiles (Campesi 2015). Passports and the country of origin also play their part as pivotal determinants of access, both in the geographical boundaries dividing countries and in the ubiquitous 'internal borders' (Fernández-Bessa 2008; Sassen 2007; Torpey 2000) that striate European Union (EU) cities and towns. The EU visa regime (see Regulation (EU) 2018/1806 of 14 November 2018) is good evidence of this relevance of citizenship for border-filtering purposes (see Salter 2006).

Equipped with the dichotomic simplicity upon which legal frameworks are generally based, border regimes take on the basic distinction between 'legal' (i.e., regular) mobilities and 'illegal' (i.e., irregular) mobilities. This critical divide is not explicitly grounded in citizenship criteria, but the relevance of this variable is particularly apparent. In the EU, this first taxonomy is supplemented by an additional classification, which is unambiguously built upon citizenship criteria-that is, the privileged legal status of EU and European Free Trade Association (EFTA) nationals and their family members (see the Citizens' Rights Directive [CRD], Directive 2004/38/EC of 29 April 2004).

This threefold division (EU citizens/'legal' third-country nationals/'illegal' third-country nationals), gradually consolidated throughout the last decades, coexists with an additional segmentation that is older than the former: differentiation between (political) refugees and (economic) immigrants. Both the EU (see Directive 2011/95/EU of 13 December 2011, Regulation (EU) No. 604/2013 of 26 June 2013 [Dublin III Convention] and Regulation (EU) 2016/399 of 9 March 2016 [Schengen Borders Code]) and its member States (MMSS) typically distinguish between mobilities allegedly driven by economic reasons and movements forced by political motives (for critique of this divide see Rigo 2017).

These various legal statuses form the basic classification architecture upon which EU border regimes are based. It is well known that this set of dichotomies has implications of utmost importance on the biographies of individuals included within these legal categories. This taxonomic framework gives shape to hierarchies of belonging and otherness and stratifications of (legal, but also social, economic and political) vulnerability (van Houtum and van Naerssen 2002). Nonetheless, the actual enforcement of these devices of migration governance does not fit into the unpliable structure of the immigration legal regulations. Analysis of the enforcement of various migration control tools lays bare this gap between legal provisions and the reality of human mobility management (Gibney 2008).

This paper aims to scrutinise a number of transformations that have shifted the aforementioned hierarchies of otherness and vulnerability without having altered bordering legal provisions. Therefore, it highlights that whereas legal regulations are a critical component of human mobility management policies, these policies may significantly change even when legal rules remain untouched.

This striking gap between legal regulations and political practices stems (to a great extent) from what has been analysed, both in the EU and elsewhere, as the multi-scalar governance of international mobility (Carmel 2013; Laine 2016; Moffette 2018; Wonders 2017). Sassen (2008) compellingly claims that in the framework of dishomogeneous globalisation processes, public policies are currently shaped by the interaction of various subnational, national and supranational institutional actors. Migration policies are 
a good case in this regard. As the negotiation and subsequent passage of the United Nations' Global Compact on Migration recently demonstrated (Ferris and Donato 2019), the governance of human mobility and borders has long ceased to be an exclusively national competence. This is markedly evident in the EU case. Migration lawmaking is essentially a prerogative of EU institutions, which, in passing legislative rules, aim to pursue what they consider to be macro-level (i.e., EU-wide) goals. In turn, national-and sometimes subnational-governments follow their own political agendas in implementing and mobilising EU-driven legal devices. As will be analysed, this frequently conflicting coexistence of national and supranational interests sometimes leads nation-state executives to adapt their longstanding migration and asylum policies to EU standards. In other cases, though, this multi-scalar scheme results in the prevalence of allegedly national interests, even with regard to critical issues such as the freedom of movement of EU citizens.

To explore these topics and perspectives, we examine Spain, a jurisdiction that received a significant number of newcomers in the 2000s (Arango 2009) and since regained momentum as a key destination of irregular migration flows in recent years (Frontex 2019). Additionally, Spain has stood out as a critical site for EU migration control innovations since the beginning of this century (López-Sala and Godenau 2017; Moffette 2018). By comparing the Spanish situation with that of other EU countries and taking into account the available data, this paper explores two recent transformations that have altered the stratification scheme put in place by EU law. The first one, addressed in the next section, concerns the fact that the majority of European jurisdictions, in contrast to EU and national law, had no actual asylum systems until the mid-2010s. We delve into how and to what extent the so-called 'migration crisis' - that is, the period initiated in 2014, characterised by the rising number of asylum-seekers arriving in the EU (Fili, Jahnsen and Powell 2018; Siegel and Nagy 2018) - has significantly changed this long-lasting situation, resulting in unpredictable consequences for border classification regimes. The second section addresses the other transformation, which concerns increasing normalisation of the deportation of EU and EFTA nationals. Again, Spain is a good national case study to approach this change in the EU borderscape (Brandariz-García and Fernández-Bessa 2017a, 2017b).

\section{Beyond the 'Legal'/'Illegal’ Migrant Hierarchy: Emergence of the Right of Asylum}

The right of asylum has been long established in the legal field. It is a centuries-old political institution, which after World War II was acknowledged by Article 14 of the 1948 Universal Declaration of Human Rights and regulated by the 1951 Geneva Convention, relating to the status of refugees. Nonetheless, Spain is a quintessential case of a jurisdiction in which the legally recognised right of asylum has been strikingly underused and insignificant, both in legal and political terms. Interestingly, this national case is not at all an exception within the EU. This assumption should be the starting point for analysis on the recent surge of the right of asylum within EU border classification regimes.

The material relevance of the right of asylum, both in Spain and the EU, can be laid bare by taking into consideration some statistical data. From 2001 to 2017, only $1.8 \%$ of the asylum applications received by EU jurisdictions were filed in Spain. In this field, Spain has ranked far below not only the critical jurisdictions of the EU asylum system (Germany, 29.6\%; France, 12.4\%; United Kingdom [UK], 8.3\%; Austria, 5.7\%) but also other Southern European nations such as Italy (8.0\%) (Eurostat 2019a). This comparison is even more revealing when taking into account the number of refugees residing in EU countries. From 2003 to 2017, an average of $0.4 \%$ of the refugees living in the EU resided in Spain (United Nations High Commissioner for Refugees [UNHCR] 2020). In this regard, Spain ranked 15 out of 28 EU States, again far lower than countries such as Germany (40.7\%), the UK (14.5\%), France (14.1\%), Sweden (7.8\%), the Netherlands (6.3\%) and Italy (4.5\%).

Spain's negligible contribution to the EU asylum system stands in stark contrast with both its demographic weight (9.1\% of the EU population in 2017) and its importance as a country of residence for migrant populations (11.5\% of third-country nationals living in the EU in 2017 resided in Spain; Eurostat 2019b) (Boza Martínez 2017). Consequently, the resident refugee population only accounted for $0.7 \%$ of the third- 
country nationals living in Spain in 2017. By contrast, refugees accounted for $10.6 \%$ of the non-EU nationals residing in the EU in 2017, and this percentage was significantly higher in countries such as Sweden (47.7\%), Malta (33.2\%), Cyprus (33.0\%), Bulgaria (29.9\%) and the Netherlands (25.1\%) (Eurostat 2019a, 2019b).

The main conclusion of this statistical overview is that the Spanish asylum system has been an irrelevant component of the EU model of political refuge. However, Spain is far from being an exceptional case. As will clarify, the available data show that at least until very recently, the vast majority of EU jurisdictions played an insignificant role within the EU asylum model, which rested upon a small number of six to eight countries.

Taking into account only the period prior to the so-called 'migration crisis', Eurostat data (Eurostat 2019a) confirm that $18 \mathrm{EU}$ nations received less than $2 \%$ (10 of them less than 1\%) of asylum applications filed in the EU from 2001 to 2013. In addition, in 2014 in seven EU MMSS (Czech Republic, Estonia, Greece, Latvia, Portugal, Slovenia and Spain), refugees comprised less than $2 \%$ of the third-country residents (Eurostat 2019a, 2019b). Further, from 2008 to 2013 in 10 EU jurisdictions the positive decision rate was lower than $20 \%$, and in two of them (Ireland and the extreme case of Greece, 1.4\%; see Cheliotis 2017; Loyal and Quilley 2016), the grant rate was even lower than 10\% (Eurostat 2019a).

This examination of the official data reveals that until the recent migration management crisis, political asylum was a phenomenon almost unknown (and unacknowledged) in the majority of EU countries, with some already mentioned exceptions (such as Austria, France, Germany, the Netherlands, Sweden, the UK and to a lesser degree Belgium, Denmark, Finland and Italy). ${ }^{1}$ The reasons that may explain this puzzling situation, which contrasts markedly with the asylum law regime, should be scrutinised. The pivotal determinant here has a political nature-that is, the moment in which the democratisation processes of EU nations were initiated. ${ }^{2}$ Late democratisation countries have featured small asylum models because they adopted international human rights standards when the 'golden age' of political asylum was concluding or had already concluded. These recently democratised EU nations joined an international protection system that began to decline with the collapse of the Berlin Wall (Gibney 2004; Valluy 2009, 2012). This political reason helps to illustrate why the irrelevance of asylum policies particularly affects Eastern and Southern European jurisdictions. The consequences of these late democratisation processes on asylum practices are particularly evident. Third-wave democratisation nations have traditionally featured very low rates of positive international protection decisions. This surely discouraged newcomers from resorting to international protection procedures to cross EU borders regularly and most likely led border control agents to overlook asylum rights in dealing with foreign individuals entering the EU.

Nonetheless, the 'migration crisis' has shifted this longstanding context at least partially. From 2014 to 2017 , the EU annual average of asylum applications escalated by $223.1 \%$ compared to those lodged between 2001 and 2013. This four-year average has at least tripled in 11 EU States, notably Bulgaria, Estonia, Finland, Germany, Greece, Hungary, Italy, Latvia, Portugal, Romania and Spain (by 262.7\%) (Eurostat 2019a). In addition, the number of resident refugees rose by 133.7\% from 2013 to 2017. This resident refugee population has at least tripled over the last four years in Bulgaria, Estonia, Germany, Greece, Latvia and Spain (by 278.7\%) (UNHCR 2020). Evidently, these changes have affected the demographic weight of refugees within the resident third national population. In 2014, refugees constituted $5.6 \%$ of all third-country nationals residing in the EU, whereas this percentage rose to $10.6 \%$ in 2017. In this three-year period, a proportion of the refugee population tripled in Germany and in countries that have been playing an insignificant part within the EU asylum system, including Cyprus, Estonia, Greece, Latvia, Lithuania, Portugal, Slovenia and Spain (increasing from $0.2 \%$ to $0.7 \%$ ) (Eurostat 2019a, 2019b).

Finally, changes fostered by the alleged migration crisis are also evident in the field of asylum decisions. From 2008 to 2013, the EU annual average rate of positive decisions was 28.8\%; from 2014 to 2017 it rose to $52.3 \%$. Moreover, the latter period not only witnessed a sharp increase in the number of asylum 
requests, but it also resulted in the positive decision rate increasing remarkably in Austria, Belgium, Cyprus, Denmark, Estonia, Germany, Ireland, Lithuania, Romania, Slovakia, Slovenia, Spain and (particularly) Greece (Eurostat 2019a).

This summary of structural asylum changes triggered by the migration crisis leads to the conclusion that although political refuge was an irrelevant (or little known) mobility management category in the majority of EU nations just five years ago, recent events have critically transformed this situation. While Germany has been the epicentre of this political and legal seism, the effects have been felt far beyond its borders. As a particularly relevant consequence of this crisis event, a wide number of EU nations, which had overlooked human mobility phenomena triggered by war and political persecution, have finally joined the EU asylum scheme. The current model is still highly unbalanced, since seven States (Austria, France, Germany, Italy, the Netherlands, Sweden and the UK) sheltered $90.1 \%$ of refugees residing in the EU in 2017, while 18 EU States took in a combined 5\% (UNHCR 2020). Still, all EU jurisdictions have been forced by recent events to join the continental system of political refuge.

This shift may be of critical importance for the classification processes inherent in bordering strategies and practices. By disregarding political asylum, many EU States' migration policies have been operating on the basis of just one dichotomy: differentiation between irregular (economic) migrants and regular (economic) migrants (López-Sala 2015). This duality has guided the operation of border control devices, including their most severe components such as immigration detention and deportation. Therefore, potential and unacknowledged asylum seekers have been frequently treated in a number of countries as irregular migrants (Aliverti 2013; Bosworth 2014; Fernández-Bessa and Brandariz-García 2018; Gibney 2008) and targeted by exclusionary legal institutions. In fact, one of the main goals of the EU's border externalisation arrangements (implemented since the early 2000s) (Akkerman 2018; Campesi 2015) has been to prevent the arrival of unwanted newcomers, immigrants and asylum seekers alike (Fischer 2012). Not in vain, this physical arrival entails - at least, legally - the right to claim rights (Fischer 2010; LópezSala and Godenau 2017), among them the right of asylum, which is increasingly evanescent in the case of diplomatic offices. ${ }^{3}$

Despite all of this, transformation of the EU asylum model might only lead to a slight alteration of the classification powers of bordering practices. The changes witnessed in recent years might spark the adaption of citizenship-based selection tasks from a binary division (regulars v. irregulars) to a threemember model (regulars/refugees/irregulars), therefore, failing to alter the core rationale of these control regimes. The classification that distinguishes between countries of origin of regular flows and those considered to found irregular flows might be slightly modified to include a third element: a small set of asylum seekers' home countries. The available international protection data seem to confirm this hypothetical scenario. For example, from 2014 to 2017, positive asylum decisions issued by EU States were concentrated to a small number of national groups, notably Syrians ( $48.3 \%$ of all positive decisions), Afghans (10.5\%), Iraqis (9.4\%) and Eritreans (6.3\%). In Spain, the narrow scope of international protection decisions is even more striking, with Syrians being granted $81.3 \%$ of all positive asylum decisions over the last four years (Eurostat 2019a).

Analysis of these data leads to two basic conclusions. First, the onset of the migration management crisis resulted in a broader continental political refuge system-albeit still markedly asymmetrical-which prior to 2014 had been practised chiefly by a core of six to eight States. With Germany leading the expansion of political asylum, almost all EU MMSS have been finally integrated into a continent-wide asylum model. ${ }^{4}$

Yet, if the agreement concluded between Turkey and the EU in March 2016 to outsource the management of asylum seeker flows (Amnesty International 2017) is taken into account, the aforementioned transformation leaves little room for optimism. Nonetheless, gradual consolidation of the right of asylum has eroded a sorting system that lies at the core of bordering practices and that in many countries (such as Spain) had categorised citizenship, almost exclusively, according to a regular/irregular binary. This will 
have implications for newcomers who will elude the most severe consequences of migration control policies more easily than those fellow nationals who arrived before them. Considering only national groups that rank high in terms of positive international protection decisions, official data show that EU countries deported 32,420 Iraqis, 28,185 Afghans, 11,390 Syrians and 4,450 Eritreans from 2008 to 2013 (Eurostat 2019a). Since then, the deportation of these asylum-seeking populations has not been put to an end; however, the effect of the deportation system on these national groups has significantly declined.

Second, this inquiry allows us to verify that the citizenship-based sorting tasks required for the swift operation of border regimes might remain relatively unaltered after recent transformations. The Spanish case, as a prototypical example of recent incorporation into the continental asylum system, shows that national border regimes may keep resorting to the established regular/irregular taxonomy by simply providing different treatment to a range of third-country foreigners who are generally recognised as asylum seekers. Syrian nationals are the most evident case, since they have been issued the majority of positive decisions in recent years. In fact, the academic literature has highlighted that some measures taken in Spain to facilitate the filing of asylum applications have been almost exclusively designed for Syrian exiles (see among others Tyszler 2017). Consequently, classification dualities may be kept alive while countries recently incorporated into the European asylum system (such as Spain) strive to meet standards of international protection.

However, it is not self-evident that national border regimes may easily overcome the challenges posed by the transformations witnessed in the last few years. Despite its deficient asylum model, Spain has long been a preferred country of destination for political exiles fleeing its former Latin American colonies, and this nexus is still in place. ${ }^{5}$ For the time being, the migration event of the last several years has led Spanish asylum policies to essentially focus on the Middle East. Still, this conception might very well be modified in the coming years. The Spanish Government, engaged in meeting European standards, might then be forced to extend its new EU-driven policies to asylum seekers travelling from countries with which it is linked by postcolonial interests. Whether this will eventuate, the analysed changes in the field of asylum practices in Spain and elsewhere in the EU are conspicuous evidence of the effect of supranational agendas on national policies, within the framework of the current multi-scalar model of migration governance.

\section{Beyond the EU Citizen/Third-Country National Hierarchy: Momentum Gained by the Deportation of EU and EFTA Nationals}

As highlighted, a second recent transformation of the EU borderscape-that is, the rising deportation of EU and EFTA nationals-is challenging the apparently consistent binaries upon which the classification powers of border regimes are based. This undermines a crucial legal prerogative that separates EU citizens from third-country nationals.

In fact, the EU citizenship legal regime portrays this type of forced return as a notably exceptional case. Both Article 45 of the Charter of Fundamental Rights of the EU and Article 20 of the Treaty on the Functioning of the EU (TFEU) set forth the right of EU citizens to freely move and reside within the Union's territory. This right is regulated by the CRD, which extends these prerogatives to designated EU nationals' family members. By virtue of Article 28 and annexes V and VII of the Agreement on the European Economic Area concluded in May 1992, this right also applies to citizens of Iceland, Liechtenstein and Norway, and their family members. Further, Switzerland joined this legal framework through the Agreement of the EU and its MMSS with the Swiss Confederation on the free movement of persons, concluded in June 1999.

Chapter VI of the CRD regulates, as a limitation to the freedom of movement and residence, the deportation of EU and EFTA nationals and their kin. As evidence of its exceptional nature, this case of forced removal lies beyond the scope of both the Return Directive (Directive 2008/115/EC of the European Parliament and of the Council of 16 December 2008) ${ }^{6}$ and the EU Commission's Return Handbook (Commission Recommendation (EU) 2017/2338 of 16 November 2017). In addition, the CRD regulation contains more requirements and safeguards than the general provisions on return procedures (see Chapter II of the CRD; 
Queiroz 2018). As far as EU and EFTA citizens are concerned, deportation orders can only have standing on reasons of public policy and public security (Article 28(1) of the CRD; see Guild in Mantu 2017) based on the personal conduct of an individual, which 'must represent a genuine, present and sufficiently serious threat affecting one of the fundamental interests of society' (Article 27(2) of the CRD). ${ }^{7}$ In addition, these deportation decisions can only be issued after having taken into account:

considerations such as how long the individual concerned has resided on its territory, his/her age, state of health, family and economic situation, social and cultural integration into the host Member State and the extent of his/her links with the country of origin. (Article 28(1) of the CRD) ${ }^{8}$

Likewise, the coercive removal of EU citizens who have the right of permanent residence can only be based 'on serious grounds' of public policy or public security (Article 28(2) of the CRD). ${ }^{9}$ Further, when the concerned EU and EFTA citizen has either resided in the host member State for at least 10 years or is underage, removal decisions can only be based on 'imperative grounds' of public security (Article 28(3) of the CRD). ${ }^{10}$ Moreover, these return orders 'shall comply with the principle of proportionality' (Article $27(2)$ of the CRD). Interestingly, Article 33 of the CRD acknowledges that these deportation orders can be part of a criminal sentence, provided that all the aforementioned requirements are met. In addition, Article 27(2) of the Directive establishes that 'previous criminal convictions shall not in themselves constitute grounds for taking' such forced return measures. ${ }^{11}$

In sum, the forced removal of EU and EFTA citizens has been regulated as an exceptional component of the EU deportation apparatus. Removal of these foreign nationals cannot be based on migration law breaches, but only on more serious motives of public policy and public security. The salience and graveness of these motives is further laid bare by the fact that the perpetration of a criminal offence is not in itself enough to warrant the issuance of a deportation order.

In marked contrast to this legal framework, empirical data illustrate that the deportation of EU and EFTA nationals is far from being a marginal phenomenon. Spain lends itself as a suitable national case to scrutinise the relevance of this migration law enforcement institution. There, national legal provisions (see Articles 15-18 of the Royal Decree [RD] 240/2007 of 16 February 2007; RD 240/2007) adopt essentially the same demanding requirements and safeguards regulated by the EU legal framework. However, the removal of EU and EFTA nationals has been playing an increasingly salient role within the Spanish deportation apparatus. Indeed, as illustrated by Tables 1 and 2, this type of deportation has been gaining significant traction over the last 10 years.

Table 1: Directive 2004/38/EC deportations enforced in Spain, 2008-2017

\begin{tabular}{|l|l|l|l|l|l|l|l|l|l|l|}
\hline & 2008 & 2009 & 2010 & 2011 & 2012 & 2013 & 2014 & 2015 & 2016 & 2017 \\
\hline $\begin{array}{l}\text { CRD } \\
\text { deportations }\end{array}$ & 21 & 11 & 27 & 57 & 166 & 208 & 269 & 398 & 374 & 340 \\
\hline $\begin{array}{l}\text { \% of enforced } \\
\text { deportations }\end{array}$ & $0.2 \%$ & $0.1 \%$ & $0.2 \%$ & $0.5 \%$ & $1.6 \%$ & $2.3 \%$ & $3.5 \%$ & $5.7 \%$ & $7.4 \%$ & $8.4 \%$ \\
\hline
\end{tabular}

Sources: Spanish Home Office (Transparency Portal), 2017 Annual Report of the Spanish National Mechanism for the Prevention of Torture (Mecanismo Nacional de Prevención de la Tortura 2018) 
Table 2: Deportations of EU and EFTA citizens enforced in Spain, 2008-2017

\begin{tabular}{|l|l|l|l|l|l|l|l|l|l|l|}
\hline & 2008 & 2009 & 2010 & 2011 & 2012 & 2013 & 2014 & 2015 & 2016 & 2017 \\
\hline $\begin{array}{l}\text { Deportations. } \\
\text { EU citizens }\end{array}$ & 104 & 135 & 232 & 298 & 398 & 433 & 448 & 560 & 515 & 427 \\
\hline $\begin{array}{l}\text { Deportations. } \\
\text { EFTA citizens }\end{array}$ & 6 & 3 & 11 & 5 & 0 & 5 & 2 & 0 & 0 & 1 \\
\hline $\begin{array}{l}\% \text { of enforced } \\
\text { deportations }\end{array}$ & $1.0 \%$ & $1.0 \%$ & $2.1 \%$ & $2.7 \%$ & $3.9 \%$ & $4.9 \%$ & $5.9 \%$ & $8.1 \%$ & $10.2 \%$ & $10.6 \%$ \\
\hline
\end{tabular}

Source: Parliamentary question made by Mr Iñárritu, MP in September 2018 (on file with the authors)

These data are particularly telling. The number of enforced deportations of EU and EFTA nationals has significantly increased in Spain over the last decade. While their relevance was negligible at the turn of the decade, they constitute more than $10 \%$ of all enforced repatriations in recent years. In contrast to its legal regulation, such forced removal orders have turned into a pivotal component of the Spanish migration control system.

Additionally, the available data reveal that a considerable number of EU and EFTA nationals have not been deported on the legal grounds established by both the CRD and the Spanish RD 240/2007. Since the passage of Organic Law 1/2015 in March 2015, Article 89(4) of the Spanish Penal Code mandates the deportation of EU nationals convicted of a criminal offence and sentenced to one year of imprisonment or more (Boza Martínez 2016; García España 2016).12 However, the data contained in Tables 1 and 2 lead us to conclude that this type of deportation, which differs from the removal orders regulated by Articles 2732 of the CRD, had been regularly enforced before the aforementioned legal reform was passed. This illustrates, once again, that the deportation of EU and EFTA nationals is a consolidated legal phenomenon in Spain.

Whether and to what extent this migration control shift has been mirrored in other EU jurisdictions remains partially unknown (Valcke in Mantu 2017).13 As mandated by Regulation (EC) No. 862/2007 of the European Parliament and of the Council of 11 July 2007, Eurostat data on the enforcement of removal orders only focus on third-country nationals, eluding any reference to the return procedures that target EU and EFTA citizens. The lack of awareness on these procedures also prevails in Spain. Despite the impetus gained by this type of deportation, the forced removal of EU and EFTA nationals is fully absent from both public and political conversations as well as academic research.

By contrast, increasing enforcement in the UK of these deportations is widely acknowledged (e.g., see Turnbull 2017). There, the repatriation of EU nationals is a critical component of the deportation apparatus, which has been gaining traction in recent years. In fact, these removals have amounted to $40 \%$ of all enforced returns in the last two years (UK Home Office 2018).

How can this normalisation of the deportation of apparently privileged EU and EFTA nationals, which contradicts EU law, be explained? In Britain, the cultural and political consequences of the two enlargements of the EU carried out in 2004 and 2007 seem to have played a pivotal role in this regard, because Polish and Romanian nationals combined account for $60 \%$ of all deported EU citizens (UK Home Office 2018; see also Evans in Mantu 2017). In Spain, these political events have been critical, too, since over the last few years Romanian nationals have accounted for around $55 \%$ of the removed EU citizens (Spanish Home Office [Transparency Portal]). ${ }^{14}$ Consequently, the accession into the EU of a number of middle-income Eastern European countries has resulted in a devaluation of EU citizenship rights, and more precisely in a significant erosion of the freedom of movement and residence (McMahon 2012; Shimmel 2006).15

Nonetheless, normalisation of the forced return of EU and EFTA nationals cannot be disconnected from the 'crimmigration' turn that has recently transformed the operation of Spain's deportation apparatus 
(Brandariz-García and Fernández-Bessa 2017a; Fernández-Bessa 2016). Increasing official concern over the deportation of convicted foreigners is encompassing non-EU citizens and EU citizens alike. The Penal Code reform passed in March 2015 and the marked salience of Romanian nationals within both the foreign prison population and the EU national deported population constitute evidence of this criminal justice system-deportation apparatus nexus.

Regardless of the similarities highlighted in this paper, there is remarkable difference between Britain and the majority of EU jurisdictions, including Spain. These EU MMSS are part of the Schengen Agreement, while the UK is not. The Schengen legal framework, which has essentially lifted internal borders, makes the ban on entry enforced against EU and EFTA national deportees (see Article 32 of the CRD) partially useless (see Hamenstädt and Evans in Mantu 2017). Further, should the deportation of EU nationals aim to expel convicted aliens, EU MMSS would have decisively resorted instead to the prisoner-transfer procedures regulated by Framework Decision 2008/909/JHA of the Council of 27 November 2008. Although these procedures appear to be useful for crime-prevention purposes for both the issuing State and the receiving State, they have been seldom enforced over the last few years (European Union Agency for Fundamental Rights 2016).

The current crisis of the European project (De Genova 2017) leads us to hypothesise that normalising the deportation of EU nationals is not destined to be a short-lived phenomenon. On the contrary, this shift lays bare that the EU citizenship rights framework is weaker than assumed. In fact, in contrast to the alleged utmost importance of these rights for the EU project, the deportation of EU nationals appears to be one of the critical resources still available to EU MMSS to favour their national interests over EU-wide legal and political principles.

\section{Conclusion}

This exploratory study addresses emerging migration control phenomena that are not yet consolidated in the EU borderscape. Therefore, more research is needed to scrutinise the implications of these changes and whether and to what extent they resonate with what is happening elsewhere.

Nonetheless, a number of conclusions can be inferred from the analysed changes. There are at least two marked differences between the two shifts explored in this paper. First, even though asylum transformations have enabled EU border regimes to evolve in an inclusive direction, the increasing deportation of EU and EFTA nationals is driving human mobility management policies in an exclusionary one. Second, xeno-racism is clearly on the rise across many-if not all-EU nations. However, the influence of this ideology on the analysed migration management policies appears to be somehow ambiguous. Despite expansive political refuge practices seeming to have partially counterbalanced the rise of xenophobic attitudes, a growing intra-EU xeno-racism has resulted in the normalisation of forced return procedures of EU citizens that were once considered exceptional in many countries.

Despite these differences, and as far as the classification tasks of bordering are concerned, both EU borderscape changes show that the binaries adopted by EU and national legal frameworks are distant from the complex operation of bordering devices, especially in a multi-scalar governance scheme like the one ruling migration management strategies and practices in Europe. Further, the examined changes reveal that both legal classifications and the hierarchies of vulnerability and 'othering' shaped by them are inherently unstable. This is unsurprising, since border regimes and hierarchies of belonging are deeply political (De Genova 2017) and highly contested (Fernández-Bessa 2019) constructions, which can hardly be stabilised by supranational and national legal regulations.

The changes explored in this paper open up new avenues for academic research and political contestation. Scholars and activists should come to terms with the fact that the deportation of EU nationals is increasingly spreading across Europe, expanding racialisation processes and eroding one of the most promising and innovative aspects of the EU project (i.e., the freedom of movement). By contrast, despite 
the right-wing populism momentum, the so-called migration crisis has opened a window of opportunity for the consolidation of asylum rights in many EU countries (Fernández-Bessa and Brandariz-García 2018). Both phenomena show the 'performativity of borders' (Wonders 2006). In other words, as has been previously stressed, they reveal that there is a significant gap between bordering legal frameworks and bordering practices, as well as between supranational goals and national interests. These gaps may be a suitable leverage point for much needed racial and social justice purposes. Not in vain, it remains to be seen whether the current EU border crisis (Vaughan-Williams 2017) is destined to lead to more exclusive and chauvinistic European societies.

\section{Correspondence:}

José A. Brandariz, PhD, Associate Professor, Facultade de Dereito, Universidade da Coruña, Campus de Elviña, s/n, 15008 A Coruña, Spain. Email: jabrandariz@yahoo.de

Cristina Fernandez-Bessa, PhD, Juan de la Cierva Senior Research Fellow, Facultade de Dereito, Universidade da Coruña, Campus de Elviña, s/n, 15008 A Coruña, Spain. Email: c.fernandezb@udc.es

\footnotetext{
${ }^{1}$ Although Luxembourg and Malta are countries with very small populations of non-European Union (EU) nationals and refugees, they could be added to this list.

2 This point is based on the so-called 'waves of democratisation' thesis (Huntington 1991), according to which a significant part of EU nations should be included within the third (and last) wave of democratisation, which begun in the 1970s. By contrast, the majority of Western European polities-among them, those characterised by having wideranging asylum systems initiated their democratisation during either the first wave (beginning in the early nineteenth century) or the second wave of democratisation (which commenced in the aftermath of World War II).

${ }^{3}$ According to the Spanish Home Office (Ministerio del Interior 2019) data, from 2010 to 2017 only 3.3\% of asylum applications were presented at diplomatic offices.

4 The most obvious exceptions are Hungary and Poland, in which positive decision rates have dwindled in recent years.

${ }^{5}$ Latin American nationals, especially Venezuelans, filed 73.4\% of the asylum applications presented in Spain in 2017 (Eurostat 2019a).

${ }^{6}$ On this, see the Court of Justice of the European Union judgement in Case C-184/16 Petrea, EU:C:2017:684.

${ }^{7}$ See Case C-193/16 E. [2017] ECLI:EU:C:2017:542.

${ }^{8}$ See Joined Cases C-331/16 and C-366/16 K. and H.F. [2018] ECLI:EU:C:2018:296.

${ }^{9}$ See Case C-145/09 Tsakouridis [2010] ECLI:EU:C:2010:708, which ruled that this provision should be interpreted in line with the concept of 'particularly serious crime' referred to in Article 83 of the Treaty on the Functioning of the EU.

${ }^{10}$ See Cases C-400/12 M.G. [2014] ECLI:EU:C:2014:9 and C-348/09 P.I. [2012] ECLI:EU:C:2012:300.

11 On this, see Case C-554/13 Z.Zh. and I.O. [2015] ECLI:EU:C:2015:377.

12 The UK Borders Act 2007 enacted a similar regulation in the United Kingdom some years before (Bhui 2007; Bosworth 2011; Kaufman 2015; Kaufman and Bosworth 2013).

${ }^{13}$ See though, Directorate-General for Internal Policies 2016 for a comprehensive report on the legal regulation of the deportation of EU and European Free Trade Association nationals in the EU member States. This report claims that France has deported 4,000-7,700 EU nationals each year from 2012 to 2015, while the number of EU citizens annually removed from Germany and Belgium (see Valcke in Mantu 2017) is counted in the hundreds.

14 Influence of the 2000s EU enlargements is also particularly striking in France, since the French Government removed around 20,000 Roma Bulgarian and Romanian nationals between 2009 and 2010 (Eremenko, El Qadim and Steichen 2017; Lafleur and Mescoli 2018).

15 In Britain, the relevance of the xenophobic wave triggered by the Brexit movement cannot be ignored (Hamenstädt and Evans in Mantu 2017; Turnbull 2017).
}

\section{References}

Aas KF (2011) 'Crimmigrant' bodies and bona fide travelers: Surveillance, citizenship and global governance. Theoretical Criminology 15(3): 331-346. https://doi.org/10.1177/1362480610396643

Akkerman M (2018) Expanding the Fortress: The Policies, the Profiteers and the People Shaped by EU's Border Externalization Programme. Amsterdam: Transnational Institute. https://www.tni.org/en/publication/expanding-the-fortress

Aliverti AJ (2013) Crimes of Mobility: Criminal Law and the Regulation of Immigration. Abingdon: Routledge. Amnesty International (2017) Greece: A Blueprint for Despair. Human Rights Impact of the EU-Turkey Deal. London: Amnesty International. https://www.amnesty.org/en/documents/eur25/5664/2017/en/ 
Arango J (2009) Después del gran boom: La inmigación en la bisagra del cambio. In Aja E, Arango J and Oliver J (eds) La inmigración en tiempos de crisis: Anuario de la inmigración en España: 52-73. Barcelona: Cidob.

Bhui HS (2007) Alien experience: Foreign national prisoners after the deportation crisis. Probation Journal 54(4): 368-382. https://doi.org/10.1177/0264550507083536

Bosworth M (2011) Deportation, detention and foreign-national prisoners in England and Wales. Citizenship Studies 15(5): 583-595. https://doi.org/10.1080/13621025.2011.583789

Bosworth M (2014) Inside Immigration Detention. Oxford: Oxford University Press.

Boza Martínez D (2016) La expulsión de personas extranjeras condenadas penalmente: El nuevo artículo 89 CP. Cizur Menor: Aranzadi.

Boza Martínez D (2017) Migrantes económicos y refugiados: La interesada creación de una falta dicotomía. In Derechos humanos en la frontera sur 2017: 42-46. Sevilla: APDHA. https://apdha.org/media/informe-fronterasur-2017-web.pdf

Brandariz-García JA and Fernández-Bessa C (2017a) La crimigracion en el contexto español: El creciente protagonismo de lo punitivo en el control migratorio. In López Sala A and Godenau D (eds) Estados de contención, estados de detención: El control de la inmigración irregular en España: 119-143. Madrid: Anthropos.

Brandariz-García JA and Fernández-Bessa C (2017b) The managerial turn: The transformation of Spanish migration control policies since the onset of the economic crisis. The Howard Journal of Crime and Justice 56(2): 198-219. https://doi.org/10.1111/hojo.12201

Brown W (2014) Walled States, Waning Sovereignty. New York: Zone Books.

Campesi G (2015) Polizia della frontera: Frontex e la produzione dello spazio Europeo. Roma: DeriveApprodi.

Carmel E (2013) Mobility, migration and rights in the European Union: Critical reflections on policy and practice. Policy Studies 34(2): 238-253. https://doi.org/10.1080/01442872.2013.778028

Cheliotis LK (2017) Punitive inclusion: The political economy of irregular migration in the margins of Europe. European Journal of Criminology 14(1): 78-99. https://doi.org/10.1177/1477370816640137

De Genova N (2017) Introduction: The borders of 'Europe' and the European question. In De Genova N (ed) The Borders of 'Europe': Autonomy of Migration, Tactics of Bordering: 1-35. Durham: Duke University Press.

Directorate-General for Internal Policies (2016) Obstacles to the Right of Free Movement and Residence for EU Citizens and their Families: Comparative Analysis. Brussels: European Parliament. http://www.europarl.europa.eu/RegData/etudes/STUD/2016/571375/IPOL STU(2016)571375 EN.pdf

Eremenko T, El Qadim N and Steichen E (2017) Southern Europeans in France: Invisible migrants? In Lafleur JM and Stanek M (eds) South-North Migration of EU Citizens in Times of Crisis: 123-148. Cham: Springer Open. https://doi.org/10.1007/978-3-319-39763-4 8

European Union Agency for Fundamental Rights (2016) Criminal Detention and Alternatives: Fundamental Rights Aspects in Cross-border Transfers. Luxembourg: Publications Office of the European Union. https://fra.europa.eu/sites/default/files/fra uploads/fra-2016-criminal-detention-and-alternatives en.pdf

Eurostat (2019a) Asylum and managed migration. Data generated from Eurostat. https://www.ec.europa.eu/eurostat/web/asylum-and-managed-migration/data/database

Eurostat (2019b) Population (Demography, migration and projections). Data generated from Eurostat. https://www.ec.europa.eu/eurostat/web/population-demography-migration-projections/data/database

Fernández-Bessa C (2008) Introducción: Los límites del control. In Fernández-Bessa C (ed) Frontera Sur: Nuevas políticas de gestión y externalización del control de la inmigración en Europa: 7-12. Barcelona: Virus.

Fernández-Bessa C (2016) El dispositiu de deportació. Anàlisi criminològica de la detenció, internament i expulsió d'immigrants en el context espanyol. Unpublished PhD Dissertation, University of Barcelona, Spain. http://diposit.ub.edu/dspace/handle/2445/97108

Fernández-Bessa C (2019) A theoretical typology of border activism: From the streets to the council. Theoretical Criminology 23(2): 156-174. https://doi.org/10.1177/1362480619827522

Fernández-Bessa C and Brandariz-García JA (2018) 'Welcoming distant refugees, barring the arrival of neighbouring migrants'-has the so-called refugee crisis shifted Spanish migration control policies? In Siegel D and Nagy V (eds) The Migration Crisis? Criminalization, Security and Survival: 321-344. The Hague: Eleven.

Ferris EG and Donato KM (2019) Refugees, Migration and Global Governance: Negotiating the Global Compacts. Abingdon: Routledge.

Fili A, Jahnsen S and Powell R (eds) (2018) Criminal Justice Research in an Era of Mass Mobility. Abingdon: Routledge.

Fischer N (2010) El 'Estado de Derecho' como forma de gobierno: El intenamiento de inmigrantes ilegales en la Unión Europea y en Francia. In Fernández-Bessa C, Silveira Gorski H, Rodríguez Fernández G and Rivera Beiras I (eds) Contornos bélicos del estado securitario: Control de la vida y procesos de exclusión social: 159-172. Barcelona: Anthropos.

Fischer N (2012) Les centres de rétention administrative: Des machines à expulser. In Bodin R (ed) Les métamorphoses du contrôle social: 115-129. Clamecy: La Dispute. 
Follis KS (2011) What is an economic migrant? Europe's new borders and the politics of classification. In Smith R (ed) Citizenship, Borders and Human Needs: 115-131. Philadelphia: University of Pennsylvania Press.

Frontex (2019) Risk Analysis for 2019. Warsaw: Frontex. https://frontex.europa.eu/publications/risk-analysis-for2019-RPPmXE

Frontex and Fergusson J (2015) Twelve Seconds to Decide. In Search of Excellence: Frontex and the Principle of Best Practice. Warsaw: Frontex.

García España E (2016) La expulsión como sustitutivo de la pena de prisión en el Código penal de 2015: ¿De la discriminación a la reinserción? Revista Electrónica de Ciencia Penal y Criminología 18(7): 1-31.

Gibney MJ (2004) The Ethics and Politics of Asylum: Liberal Democracy and the Response to Refugees. Cambridge: Cambridge University Press.

Gibney MJ (2008) Asylum and the expansion of deportation in the United Kingdom. Government and Opposition 43(2): 146-167. https://doi.org/10.1111/i.1477-7053.2007.00249.x

Huntington SP (1991) The Third Wave: Democratization in the Late Twentieth Century. Norman: University of Oklahoma Press.

Huysmans J (2006) The Politics of Insecurity: Fear, Migration and Asylum in the EU. Abingdon: Routledge.

Kanstroom D (2012) Aftermath: Deportation Law and the New American Diaspora. Oxford: Oxford University Press.

Kaufman E (2015) Punish and Expel: Border Control, Nationalism, and the New Purpose of the Prison. Oxford: Oxford University Press.

Kaufman E and Bosworth M (2013) The prison and national identity: Citizenship, punishment and the sovereign state. In Scott D (ed) Why Prison? 170-188. Cambridge: Cambridge University Press.

Lafleur J-M and Mescoli E (2018) Creating undocumented EU migrants through welfare: A conceptualization of undeserving and precarious citizenship. Sociology 52(3): 480-496. https://doi.org/10.1177/0038038518764615

Laine JP (2016) The multiscalar production of borders. Geopolitics 21(3): 465-482. https://doi.org/10.1080/14650045.2016.1195132

López-Sala A (2015) Exploring dissuasion as a (geo)political instrument in irregular migration control at the southern Spanish maritime border. Geopolitics 20(3): 513-534.

https://doi.org/10.1080/14650045.2015.1025384

López-Sala A and Godenau D (2017) Introducción: El estudio del control migratorio en España. In López-Sala A and Godenau D (eds) Estados de contención, estados de detención: El control de la inmigración irregular en España: 528. Barcelona: Anthropos.

Loyal S and Quilley S (2016) Categories of state control: Asylum seekers and the direct provision and dispersal system in Ireland. Social Justice 43(4): 69-97.

Mantu SA (ed) (2017) Expulsion and EU citizenship. Nijmegen Migration Law Working Papers Series 2017/02. Nijmegen: Radboud University Nijmegen. https://repository.ubn.ru.nl/handle/2066/179152

McMahon S (2012) Assessing the impact of European Union citizenship: The status and rights of Romanian nationals in Italy. Journal of Contemporary European Studies 20(2): 199-214. https://doi.org/10.1080/14782804.2012.685391

Ministerio del Interior (2019) Ministerio del Interior: Anuarios. https://www.interior.gob.es/gl/web/archivos-ydocumentacion/documentacion-y-publicaciones/anuarios-y-estadisticas

Moffette D (2018) Governing Irregular Migration: Bordering Culture, Labour, and Security in Spain. Vancouver: UBC Press.

Queiroz B Menezes (2018) Illegally Staying in the EU: An Analysis of Illegality in EU Migration Law. Oxford: Hart.

Rigo E (2017) Re-gendering the border: Chronicles of women's resistance and unexpected alliances from the Mediterranean border. ACME: An International Journal for Critical Geographies 18(1): 173-186.

Salter MB (2006) The global visa regime and the political technologies of the international self: Borders, bodies, biopolitics. Alternatives 31(2): 167-189. https://doi.org/10.1177/030437540603100203

Sassen S (2007) A Sociology of Globalization. New York: W.W. Norton.

Sassen S (2008) Territory, Authority, Rights. 2nd ed. Princeton: Princeton University Press.

Shimmel N (2006) Welcome to Europe, but please stay out: Freedom of movement and the May 2004 expansion of the European Union. Berkeley Journal of International Law 24(3): 760-800. https://doi.org/10.15779/Z38NW8R

Siegel D and Nagy V (eds) (2018) The Migration Crisis? Criminalization, Security and Survival. The Hague: Eleven.

Torpey J (2000) The Invention of the Passport: Surveillance, Citizenship and the State. New York: Cambridge University Press.

Turnbull S (2017) Immigration detention and the racialized governance of illegality in the United Kingdom. Social Justice 44(1): 142-164.

Tyszler E (2017) La frontera hispano-marroquí, zona de selección de las personas candidatas a la inmigración hacia Europa. In Derechos humanos en la frontera sur 2016: 25-36. Sevilla: APDHA. 
UK Home Office (2018) National Statistics: How Many People are Detained or Returned? London: UK Home Office. https://www.gov.uk/government/publications/immigration-statistics-year-ending-june-2018/how-manypeople-are-detained-or-returned\#returns

United Nations High Commissioner for Refugees (2020) UNHCR Statistical Yearbooks. http://www.unhcr.org/statistical-yearbooks.html

Valluy J (2009) Rejet des exilés: Le grand retournement de droit de l'asile. Bellecombe-en-Bauges: Editions du Croquant.

Valluy J (2012) De l'asile aux répulsions: La radicalisation des frontières. In Agier M (ed) Réfugiés, sinistrés, sanspapiers: Politiques de l'exception: 84-95. Paris: Téraèdre-Le Sujet dans la cité.

van Houtum $\mathrm{H}$ and van Naerssen T (2002) Bordering, ordering and othering. Tijdschrift voor Economische en Sociale Geografie 93(2): 125-136. https://doi.org/10.1111/1467-9663.00189

Vaughan-Williams N (2017) Europe's Border Crisis: Biopolitical Security and Beyond. Oxford: Oxford University Press.

Wonders NA (2006) Global flows, semi-permeable borders and new channels of inequality: Border crossers and border performativity. In Pickering S and Weber L (ed) Borders, Mobility and Technologies of Control: 63-86. New York: Springer.

Wonders NA (2017) Sitting on the fence-Spain's delicate balance: Bordering, multiscalar challenges, and crimmigration. European Journal of Criminology 14(1): 7-26. https://doi.org/10.1177/1477370816640140 